\title{
Fine and ultrafine particles emitted from laser printers as indoor air contaminants in German offices, Tao Tang, Julia Hurraß, Richard Gminski, Volker Mersch-Sundermann (2011) Environ Sci Pollut Res; DOI: 10.1007/s11356-011-0647-5
}

\author{
Michael Wensing
}

Received: 5 March 2012 / Accepted: 20 March 2012 /Published online: 14 April 2012

(C) Springer-Verlag 2012

In the acknowledgments to their article, the authors thank me for my critical review of their data and for the discussion of the results and conclusions of their study. It is quite correct that in connection with the concluding report of the study, which was commissioned by the Federal Institute for Risk Assessment (Bundesinstitut für Risikobewertung or BfR), I undertook a critical examination of their measurement methods, results, and conclusions. The results of my evaluation which I communicated in writing to the BfR are not however to be found in the present article, and I neither actively partic- ipated in writing this publication nor performed any advisory function. In addition, our own measurements in regard to fine particles show totally different results (Salthammer et al. 2012).

\section{Reference}

Salthammer T, Schripp T, Uhde E, Wensing M (2012) Aerosols generated by hardcopy devices and other electrical appliances. Environ Pollut. doi:10.1016/j.envpol.2012.01.028

Responsible editor: Philippe Garrigues

M. Wensing $(\bowtie)$

Department Material Analysis and Indoor Chemistry,

Fraunhofer Wilhelm-Klauditz-Institut,

Bienroder Weg 54E,

38108 Braunschweig, Germany

e-mail: michael.wensing@wki.fraunhofer.de 